\title{
THE RELATIONSHIP BETWEEN E- MARKETING MIX STRATEGY AND INTEGRATED MARKETING COMMUNICATION: A CONCEPTUAL FRAMEWORK
}

\author{
Masri bin Abdul Lasi, \\ Faculty of Business, \\ City University of Malaysia, Petaling Jaya, \\ Selangor, Malaysia
}

\begin{abstract}
In the last three decades, the global economy and the corporate world have seen massive technological shifts, especially in the field of IT and company owners, who have to come up with a new concept. This thesis aims to provide useful insight into the relationship between electronic marketing mix strategy and integrated marketing communication. This paper examines whether e-marketing impacts integrated marketing communication. The researcher stressed and deliberated the requisite e-marketing formula of $2 \mathrm{P}+2 \mathrm{C}+3 \mathrm{~S}$ (Personalization, Privacy, Customer Service, Community, Site, Security and Sales Promotion). This role has revolutionized the process by which the organization interacts both to existing and prospective consumers and maximize the investment return and reduces the cost of reaching customers with an E-Marketing approach.
\end{abstract}

Keywords - E-Marketing, Integrated Marketing

Communication, Marketing Mix, Marketing Management,

\section{INTRODUCTION}

Marketing mix proposed by E. Jerome in 1960 Jerome McCarthy provided them with a management approach covering analysis, customer behavior, market research and planning. Phillip Kotler popularized this approach and helped spread the 4 Ps model and McCarthy's 4 Ps have been widely adopted by both marketing academics and partitioners. Keelson et al., (2012). The popular marketing mix has been practiced in existence since 1967 for more 53 years as the 4Ps (Product, Price, Place and Promotion). Kotler \& Armsrong, (2010); Kalyanam \& McIntyre, (2002).

This marketing mix is the set of controllable variables that the firm can use to influence the buyer's response and could help the company to develop a unique selling point as well as a

\author{
Sallina Mohamed Salim \\ City Education Online \\ City University of Malaysia, Petaling Jaya, \\ Selangor, Malaysia
}

brand image to attract customer loyalty Masri and Tan (2020). With the rise of the internet and the advent of new concept like social media, E-commerce, and digital marketing, academics and partitioner started criticist and questioning the relevance of the classic four Ps as model of marketing. Some proclaimed that the four Ps model is dead. Brands like google never really advertised, yet they became popular. The marketing has a much better and higher standing today in corporate world, initially marketing was seen as mainly advertising function or more broadly communication function. The marketing opened companies' eyes to seeing the consumers as the center of the profit-making universe.

The role of internet marketing in achieving the Integrated Marketing Communication (IMC) objective has continued to gain broader debate between scholars and practitioners Weinstein, (2008); Preeti, (2018), Rahul, (2016). IMC stems from the need for effective coordination of organizational strategic communication strategies in a clear, concise, credible, competitive and consistent manner that encourages the exchange of a straightforward message on corporate goods and services.

\section{E- MARKETING MIX ELEMENTS}

The biggest advantage of e- marketing is that the internet makes it possible to provide services at every stage of selling the products. E-marketing is a set of actions which are used to strengthen business position according to the 4P model, incorporating interactively and its elements, but not excluding them as separate elements and evaluating when making marketing decisions. The previous research by Azahari et. al, (2018). Described the E-marketing mix using (4Ps + 3Ps), + $\mathrm{S} 3 \mathrm{P} 2 \mathrm{C} 2$ in order to retain the unique 4Ps (Product, Price, Place, and Promotion) plus additional 3Ps (Physical 


\section{International Journal of Engineering Applied Sciences and Technology, 2020 \\ Vol. 5, Issue 6, ISSN No. 2455-2143, Pages 40-48 \\ Published Online October 2020 in IJEAST (http://www.ijeast.com)}

Environment, Process and People) and they also added Site Design, Security, Sales Promotion, Personalization, Privacy, Customer Service, and Community. Azahari, Raemah \& Yasmin (2013).

In this paper, the researcher will explore the formula of $\mathrm{E}$ marketing which represented by $2 \mathrm{P}+2 \mathrm{C}+3 \mathrm{~S}$ (Personalization, Privacy, Customer Service, Community, Site, Security and Sales Promotion). These function from the framework of an emarketing strategy. E-marketing is unique as it has a series of specific, relational functions that can be presented by the $2 \mathrm{P}+2 \mathrm{C}+3 \mathrm{~S}$ formula. The mentioned functions of the emarketing form the framework of an e-marketing.

E-marketing used to strengthen business position according to 4Ps model, incorporating interactivity and its elements not excluding them as separate elements and evaluating when making marketing decision. The two main features in emarketing mix are to controlled area within the company scope and to properly coordinated marketing mix gives company synergetic effect. The overall result of marketing mix impact is bigger than the effect of separate constituent elements Masri and Tan (2020). If synergistic effect does not occur, it means that marketing mix (action and decision) is managed badly. In fact, a successful business depends on numerous internal and external elements Azahari et. al, (2018).

E-marketing is often identified as an integral part of a company overall marketing strategy, so it means that overall marketing strategy objectives can be accommodated to it. Objectives that are narrower in scope are attributed to the internet marketing. E-marketing strategy includes a range of measures, which even in today's aggressive competitive environment, can bring a higher profit and win greater market share. Scientific literature identifies a variety of processes for developing marketing strategies but internal and external environment analysis, setting objectives, pursuing the goals and opportunities, and choosing the core strategy. Marketing mix element can directly influence company performance and guidance in making a right marketing investment. Masri and Tan (2020).

\section{A. E- MARKETING MIX - 4PS+2PS+2C+3S MODEL}

As discuses in previous chapter, McCarthy version of marketing mix is composed of product, price, place and promotion. Each of these 4Ps comprise a number of twelve managerial policies, thus including other sub mixes within each Ps. As noted by Masri \& Tan (2020), the marketing mix are collection from a thousand of micro-elements clustered together in order to achieve customer loyalty and simplified managerial activity. The validity or the exclusion of the traditional mix in the digital context is a matter of if and how it is possible and convenient to extend the number of elements it includes or to dismiss it and create a new one.

The market and business took place in a number of related changes of information technology that led to another attitude towards communication and the exchange of the emergence. The internet, which is a new form of communication, combines a large and extensive network, which covers different internet users/consumers. In this case, both consumers and advertising suppliers may have a role in online information provider. Users have the ability to create websites, to publish article in it or promote various products.

Van Waterschoot and Van den Bulte (1992) has pointed out that the components of communication address barriers to wanting, whereas the sales promotion function addresses barriers to acting. They observed that triggers to customer action seem necessary in certain situation to induce the exchange. Masri and Tan (2020) they found out that sales promotion is situational function, and marketing mix can be reclassified into the basic mix and situational mix. Van Waterschoot and Van den Bulte (1992) has classified and summarized the model of marketing mix into following axioms:

- Axiom 1: Marketing functions are the appropriate properties for the classification of marketing tools.

- Axiom 2: Some function is essential, and others are situational in nature.

- Axiom 3: Some function has a moderating effect across other marketing functions and are called overlapping function.

- Axiom 4: Function are accomplished by marketing tools.

- Axiom 5: A tool can serve one or several functions,

Based on the above axioms, Kalyanan \& McIntyre (2002) created a new E-marketing model as illustrated in table 1 and mapped the marketing tools to the new e-marketing mix model.

Table 1. E-Marketing tools and E-Marketing Mix Model

\begin{tabular}{|c|c|}
\hline $\begin{array}{c}\text { E- Marketing Mix } \\
\text { Elements }\end{array}$ & Mapped E-Marketing Tools \\
\hline \multirow{3}{*}{ Product } & Assortment \\
\cline { 2 - 2 } & $\begin{array}{c}\text { Configuration Engine - configure } \\
\text { products }\end{array}$ \\
\cline { 2 - 2 } & Planning and Layout tools \\
\hline \multirow{2}{*}{ Price } & Dynamic Pricing \\
\cline { 2 - 2 } & Forward Auctions \\
\cline { 2 - 2 } & Reverse Auction \\
\cline { 2 - 2 } & Name your price \\
\hline \multirow{2}{*}{ Place } & Affiliates \\
\cline { 2 - 2 } & Remote Hosting \\
\hline
\end{tabular}




\begin{tabular}{|c|c|}
\hline \multirow{4}{*}{ Promotion } & Online Advertisements \\
\hline & Outbound Email \\
\hline & Viral Marketing \\
\hline & Recommendation \\
\hline \multirow{3}{*}{ Personalization } & Customization \\
\hline & $\begin{array}{l}\text { Individualization- send notice of } \\
\text { individual preferences }\end{array}$ \\
\hline & Collaborative Filtering \\
\hline Privacy & Privacy Policy \\
\hline \multirow{4}{*}{ Customer Service } & FAQ \& Help Desk \\
\hline & Email Response Management \\
\hline & $\begin{array}{c}\text { Chat rooms between customer and } \\
\text { supporting staff }\end{array}$ \\
\hline & Order tracking \\
\hline \multirow{3}{*}{ Community } & Product discussion among customers \\
\hline & User Rating and Reviews \\
\hline & Registries and Wish Lists \\
\hline \multirow{3}{*}{ Site } & Homepage \\
\hline & Navigation \& Search \\
\hline & Page Design \& Layout \\
\hline Security & Security tool(s) \\
\hline \multirow[b]{2}{*}{ Sales Promotion } & E-coupons \\
\hline & Discount \\
\hline
\end{tabular}

4Ps+P2C 2 S 3 model is an improvement over the 4Ps model by adding more components to reflect the E-Commerce environment. In addition, the e-marketing tools, which can influence consumer retention on the Internet (Noor \& Ali, 2006) and play an important role in the formation of an effective e-marketing strategy. Kalyanam \& McIntyre, (2002) and Krishnamurthy, (2006), are mapped into each component of the model. In this way, it is easy to evaluate the performance of each component in this model. Setiyaningrum et al. (2015) and Meng \& Chatwin (2012).

As a result, the social networking sites can greatly affect online consumers' buying decision. This concern has been addressed in the 4Ps + P2C 2 S 3 model. In addition, despite the high number of online shoppers, 150 million (Teodorescu, 2008), it seems that only a small percentage-12\%- of the European Internet users are truly confident when buying online (European Commission, 2009) due to the security and privacy concerns which have also been addressed in 4Ps + P2C 2 S 3 model as well.

Based on the above comparisons, the 4Ps + P2C 2 S 3 model is the most suitable choice for this research. According to Sam and Chatwin (2012), The measurement 4Ps + P2C 2 S 3 model, results of e-marketing mix elements indicate that it can make a big difference if the relative weights of the emarketing tools are ignored. As a result, the relative weights of e-Marketing mix play an important role in measuring the emarketing mix elements. If online business can measure their e-marketing mix elements accurately, it can certainly increase sales revenues.

\section{B. PRODUCT}

The E-marketing mix many similarities to the variety selection practices of merchants. Azahari et, al. (2018) in their research only concentrate on some of the distinctive abilities in the online setting. In this research, researcher identifies emarketing products as a product in a virtual environment and can be divided into a nature of (1). Physical Product, which is intangible product for instance household appliances, books, cars, mobile phone and etc., these products has no possibilities to test them when buying online. (2). Digital Products- goods existing only in cyberspace they include software, e-books, pictures, audio and video e-products. (3). Services - this produce cannot be separated from the service provider, it is intangible, they are used and supplied at the same time when two part, i.e. the service provider and the user, are present.

These services include traveling, distance learning, virtual games and so on. Technology allows the customer to save money, time and this in turn contribute to a higher value of goods on the internet. In this challenging market, the organization is required to provide most complete information about the product on the website.

Symbolic consumption in marketing plan could likely to promote customer to purchase a product or service which could reinforce their identities. Wanrudee, T. \& Xiaobing, L., (2018). Aron. O, \& Nima, H. (2015) found out when there is complementary of promotion and the customer-centered approach will improve product success probability. Rather than apply one in isolation, combining with management of brand and relationship with customer, new product success is likely to achieve, Masri and Tan (2020).

\section{PRICE}

Pricing strategy is essential component of marketing mix. (Nebojsa S. D., \& Piyush S., (2015). Price is the amount of costumer willingly to pay on the product/services. The focus on this paper is on the argument of digital pricing. The internet is seen as an efficient market, since it is marked by such features as lower prices, increased price flexibility, frequent but less significant changes in prices. Lower costs of commercial activities on the internet lead to lower prices, reduces need for staff, no expenses for premises rent and maintenance.

Buying agents contribute to lowering the price such as public presentation of benchmarking results, reverse auction - buyers set the price and the supplier tries to meet the offer, tax-free 


\section{International Journal of Engineering Applied Sciences and Technology, 2020 \\ Vol. 5, Issue 6, ISSN No. 2455-2143, Pages 40-48 \\ Published Online October 2020 in IJEAST (http://www.ijeast.com)}

zones is the lower taxes are imposed as there are no states borders, venture capital- most e-businesses are funded by venture capital funds and the letter is focused in the long-term rather than faster and higher profits.

Due to constantly changing customer needs online prices, it caused variety of purchasing behavior and price changes. The organization is necessary to combine and apply complex pricing methods, principles and strategies, in particularly to those that are considerably new, it is including dynamic pricing. The internet is dominated by harsh competition thus it requires heavy fixed costs on advertising to attract and retain customers online. According to world studies up to $40 \%$ of the internet revenue is allocated to e-marketing

John G.D (2017) has found that a temporary price promotion can beneficial since it can result in uplift sales and maintain product's normal price despite the high cost. However, price promotion might be seeming "lighter" to the non-buyer. They may get reassured that the brand quality might be less quality which result in price promotion, another form of advertising. This after-effect could affect brand loyalty. Even the loyalty could be light and short in duration. Leandro, A.G., Juan, M.S., Jonny, M.R. (2018) found out that the price sensitivity could result in vary effect of promotion depending on the nature and type of store format. This can be the result of different level of economic development in regions. When marketing mix is customized to specific market characteristic, it can only be effective.

\section{PLACE}

The place is where promotion takes place affects quality of marketing and thus brand loyalty. Masri \& Tan (2020). A good place improves the credibility of the store image and stimulates consumption growth (Chen, 2018). The corporate image would promote customer satisfaction. Muhammad S.R. \& Aahad M.O. (2015). Laura,G. ,Maria, C.M. \& Angelo, D.G. (2015) found out that mega-event improve public awareness to the targeted resources for minor place such as Monza and Brianza province. Masri and Tan (2020), Place is an important attribute to the organization and could display brand loyalty despite any degree of marketing effort from other brand to initiate brand shift.

In e- marketing similarly to traditional marketing there are the same channels intermediaries- wholesalers, to buy product from manufacturers and sell to retailer. Retailers to purchase products from wholesalers and sell them online directly to customers. Brokers to help to conduct transaction between buyers and sellers and agent to help to conduct e-transactions, but unlike brokers they represent either buyer or seller. The internet, i.e. virtual space, allows transforming the mediation process efficiently and inefficiently acting agents are removed from the distribution channel and functions are transferred to other intermediaries. The discussion on place or distribution channel strategy will include the substantially new elements including remote hosting. It is utilizing a technology called remote merchant hosting, the portal can be hosting a mirror image of the site. Seller rents the space on these shopping sections and the portal take the purchase order and forward the purchase order to the sellers.

\section{E. PROMOTION}

In the field of marketing, marketing communication is evolving and changing, there is rise in new tools, theories, techniques, technological changes, and cultural dynamics all combine to create impact on the way marketers are communicating their message to the targeted audience. Symbolic consumption in marketing plan could likely to promote customer to purchase a product or service which could reinforce their identities Wanrudee, T. \& Xiaobing, L., (2018). Masri and Tan (2020), found out when there is complementary of promotion and the customer-cantered approach will improve product success probability. Rather than apply one in isolation, combining with management of brand and relationship with customer, new product success is likely to achieve.

With the rise in e-commerce, sales promotion activities have increased drastically online. Sales promotion instruments includes coupon, rebates, free or low-cost gift, contest, banner add and sponsored link. Promotion online is directed to consumers themselves and the impact of the sales promotion can therefore be easily measured based on the level of interaction in the website.

For instance, most of the online service providers like the software producer organization often gives free sample to the consumer for test over a specified period of time after which they are required to pay for the product or service if they so wish to continue using the service. Organization also uses contest for a product or gift to keep their customers or fan based excited and interacting in the website. It could also be a sweettalks where there is no contest but a thing of chance thereby making the website stakeholders more excited over time. Azahari et, al. (2018).

\section{F. PERSONALIZATION}

Personalization refers to method of individualizing an impersonal computer networked environment such as websites that greet users by their name, providing personalized information. Azahari et. al (2018). This is an extremely important component of e-marketing, as it recognizes and establishes a direct, personal relationships with customer. This way, some of vital information about the customer is gathered which helps the company to customize its service to that 


\section{International Journal of Engineering Applied Sciences and Technology, 2020 \\ Vol. 5, Issue 6, ISSN No. 2455-2143, Pages 40-48 \\ Published Online October 2020 in IJEAST (http://www.ijeast.com)}

particular customers. For example, if a visitor to Lazada.com has been searching online product, the information of the product will be displayed to the user next time. Typically, users register with a site and create a profile and when the users return, it will show the information that they signed up for or find relevant.

\section{G. PRIVACY}

Privacy is often referred to as the seclusion theory; access control, which places its emphasis on laws and standards that enable persons to reasonably regulate the information that they are giving up Azhari et. al. (2018). Privacy policy addresses what information that what information is being collected and how it will be used and whether the information will be sold or shared with third parties. This factor is closely related to personalization, that is, how the information about individual user is obtained and stored. Also, who will be able to use it and for what purpose. Thus, before initiating an e-marketing strategy, the company must put in place a policy for the collection, storage and usage of data.

\section{H. CUSTOMER SERVICE}

Customer service is very important technique in implementing e-marketing for an organization. The newly implementation strategy is Frequently asked question (FAQ) and help desk. Customer will be click on the link which leads to a help desk or support page that provides users to the specific customer support tools. Azahari et.al. (2018). Chat room is a virtual space where user can communicate each other via online using special software. For example, City University Malaysia used Eva Chat in their website, so that if there any issue on inquiry pertaining the program, the user can chat to ask a question without waiting long hour to get response.

This is a necessary feature in any transactional service, and any e-marketing programme will be incomplete without it. Based on the research by Ahmed and Masri (2020), they identified that service quality is the measurement factors have significant impact on the customer satisfaction and loyalty towards the organization. As with other elements of the $2 \mathrm{P}+2 \mathrm{C}+3 \mathrm{~S}$ model of e-marketing, customer service is a moderating factor that applies to all the 4Ps separately.

\section{COMMUNITY}

In terms of the e-marketing, community means that getting customers to interact with one another in a way that increase the benefits of coming to the sponsor web site Azahari et, al. (2018). This include the virtual community where the customer communicates each other. The community also refer to the group of clients or customers who interact with the company. The larger the network and its reach, the better it is for the success of the e-marketing programme.

Now days, the advancement of ecteronic WOM (e-WOM) has opened avenues for new forms of integrative marketing communication to the community, instead of the knitted traditional one-way communication between the organization and customers via mass communication channels (Kim, Wang, Maslowska, \& Malthouse. (2016), Rialti et, al. (2017). In particular, it different to the traditional word of mouth in three aspects, first, e-WOM is presented in the written form, and it can be read; second, it exists in public online forums or website, available for any users, consumer or brand to observe and third, once online, e-WOM is electronically stored and can be used in future Kim et al. (2016). In this case, e-WOM, can be describe as one of the parts of community advancement in e-marketing.

\section{J. SITE}

Site refers to the location where the e-marketing activities take place. Generally, the site is the website Site refers to the location where the e-marketing activities take place. The organization who engaged in online or traditional business, a well design of website can be considered as a powerful online portfolio. The website is an online identity of a company who involved in e-business. In this era of advanced technology, electronic e-commerce has highly dominated the business practices Azahari et., al. (2018).

\section{K. SECURITY}

Along with the personalization and privacy a related concern is with security of the website itself. Azahari et al. (2018). The reality is that in these days almost anyone could create anonymous website with little effort and knowledge. On other hand, detecting how credible and reliable a site is quite difficult task. Credibility is that variable, which is not easily measured, if we were to discuss in terms that are more technical on the contrary, people usually recognize how credible a site is by considering other factors. Abdelwahab et., al. (2015). Credibility is necessary in order to resort to your service, download software, click on your ads, and eventually to make people register. Therefore, the credibility of a website can be identified somewhat with the idea of a flourishing business. Ahmed and Masri (2020).

Privacy policies play an important role in E-marketing. While the electronic marketplace is growing rapidly, there are also indications that consumers are wary of participating in it because of concern about how their personal information is 


\section{International Journal of Engineering Applied Sciences and Technology, 2020 \\ Vol. 5, Issue 6, ISSN No. 2455-2143, Pages 40-48 \\ Published Online October 2020 in IJEAST (http://www.ijeast.com)}

used in the online marketplace. Privacy also one of the essential elements in e-marketing mix, in order to ensure the security of the transactions over the internet, which should not be accessible to any outsider and the information collected from the consumers should be kept private and confidential.

\section{SALES PROMOTION}

This is also commonly adopted in traditional marketing, and involves offers and discount etc., to attract customers and boost sales. Azahari et.,al. (2018) note that E-marketers duty is to discover new tactics and new prospects for developing effective communication. In e-marketing, sales and promotion is a good way to achieve sales target in short period. Therefore, marketing practitioner shall understand the customer-brand relationship (CBR) which involves brand loyalty and which aspect of marketing to invest on is much relatively important to ensure a wise marketing investment Masri \& Tan. (2020).

Sales promotion could directly point out the significance of their advantages and their respective marketing positions Chen (2018). When the promotion emphasizes the availability of early bird discount or credit term (online payment discount), which can relieve purchaser's financial aspect in the long term, the brand loyalty could be maximized with the assistance of promotion

\section{INTEGRATED MARKETING COMMUNICATION}

Integrated marketing communication is a strategic business method used for preparation, developing, executing, assessing, evaluating, organizing and convincing brand communication strategies with buyers, customers, prospective clients, suppliers and all other stakeholders in the organization. Orasmäe (2017) noted that all communication resources perform best if they are integrated into unity rather than operating in isolation. A sum is greater than their parts, provided they speak with one voice at all times. Orasmäe, (2017). Caemmerer (2009) confirms Orasmäe's (2017) that IMC is a marketing approach that incorporates all forms of marketing tools to work together in a harmonized and costeffective manner.

Clear and concise goals clearly communicated to all in the company would help the organization to achieve effective integrated marketing objectives. Pawar (2014) identified three categories of goals that could be used by the organization to develop and implement a strategic communication plan. Your integrated marketing communication strategy should be able to answer the following questions: is the company trying to increase brand awareness, increase sales revenues, develop and build more customer relationships? Once the company has made a clear decision on the purpose and objectives of the
IMC, it can be calculated, analyzed and managed by the marketing team (Helen, 2018).

By effectiveness of online marketing in integrated marketing communication framework we mean the extent online success in online marketing can be measured over time by the organization. Literature have revealed certain criteria an organization can use in measuring the success of its online marketing efforts including: the number of unique visitors, the number of page viewed per visit (bounce rate), the number of repeated visit, the minutes an individual visitor spend in on the website per visit, the behavior of the visitors on the site (copying, reading among others), the number of comments on the post, the number of e-mails received from customers and many others. Strauss \& Raymong. (1999).

As noted earlier, the world of information technology is constantly revolving and changing, where innovative technology is changing consumer behavior on daily basis. Consumer attention are being caught by different thing and what matters most to the consumers are changing on daily basis so is the online marketing trend. Brian. (2018). Organization must therefore make adequate effort to explore the digital marketing trends and position their promotional tools to reach as many effective customers as possible with minimal cost. Below are the trending digital marketing tools that can be employed by organization to increase their online presence and remain competitive in the market.

\section{A. ARTIFICIAL INTELLIGENCE.}

One unique benefit of digital marketing is that it reaches, engages and influences more audience at minimal cost than offline marketing. The latest technology employed by organization to minimize their expenditure is artificial intelligence (Nidhi, 2018). Artificial intelligence performs several roles that can be performed by the organization employees saving the organization marketing cost. Ai can collect data of organization customers from comments, blogs, social media for utilization, analyse consumer behaviour, and above all, can be used to answer several customers complaints and enquiries as human being would ordinarily.

Nidhi (2018) following the report by Gartner, noted that by 2020 , it is presumed that 85 percent of organization interacting with its customers will be carried online through artificial intelligence. One peculiar ai technology popular today is chatbots. Brian (2018) argued that chatbots is the solution to organization customer service that can interact with organization customers need in real time. The chatbots has the ability to chart with customers and responds to customer needs whether at night, day and anytime. 


\section{International Journal of Engineering Applied Sciences and Technology, 2020 \\ Vol. 5, Issue 6, ISSN No. 2455-2143, Pages 40-48 \\ Published Online October 2020 in IJEAST (http://www.ijeast.com)}

It has saved most organization the stress of employing staff from different countries with different daytime. Nidhi (2018) predicted that by 2022 chatbots is designed to save organization over $\$ 8$ billion marketing cost per annum. Brian (2018) further noted that Service has predicted that by 2025 , about 95 per cent of consumer- brand discussion will be powered by Ai. Most organization have started to adopt chatbots to replace human in attempt to reduce cost and provide better response to customers. It facilitates better ads targeting based on consumer surfing behaviour.

\section{B. VIDEO MARKETING}

Another trending online marketing tool is content video marketing. Forbe (2017) survey revealed that video consumption online grows by 100 percent every year and will continue to grow every year. Video consumption is projected to claim 80 percent of traffic online by 2021 . Nidhi. (2018) and 70 percent traffic by 2019. Forbe, (2017). Brian (2018) observed that adding video content to e-mail marketing will likely increase the click through of the content by at least 200-300 percent. It was equally revealed that 70 percent customers surveyed are likely to purchase organisation product and service after watching video about the products.

\section{INFLUENCER MARKETING}

This is yet another trending marketing platform online employed by several organization to reach a targeted large audience. Nedhi (2018) observed that survey carried by the organization revealed that 58 percent of marketers interviewed favoured the integration of influencer marketing to all organisation marketing activities. 39 percent of the sampled respondent expect their budget on influencer marketing to increase.

It is important that as product review for consumer purchasing a product on an e-commerce website, so does influencer marketing important for consumer to make decision regarding a product. Brian (2018) noted that consumers purchase more of the product if someone they trust recommend the product. An influencer can be a celebrity, popular social media account among others. Someone with high level of followers can advise the company products and everyone would want to use it. People tends to copy a celebrity lifestyle and once they recommend a product it becomes hot sales.

\section{MICRO MOMENT}

Micro moment is what most popular bloggers have learnt over the year and have woo them several traffic and fans. Google see micro moment as the period where an individual wish to learn something, know about something or looking for something through their phone.

Marketing experts revealed that the ability of organisation to easily capture their message in a small concise and clear language will win them more consumers. Brian (2018) shared the view that consumers are faced with several pressing needs demanding their time as such rarely have time for long explanation but short and rich statement. It has been argued that consumers in US spend at least 4.7 hours a day with their phone and visiting social media on average at least 17 times a day. Organisation can therefore design their product and service message in a concise and clear manner.

\section{E. BIG DATA}

Big data is not just trending in marketing industry, it has also become a major weapon employed by organisation to compete favourably in other industry. Demers, (2017). There is virtually no limit to the amount of data an organisation can collect and this data can be analysed with artificial intelligence providing much insight on the organisation customer behaviours. What matters most to the consumers are revealed by big data. Whether operating in small scale or large scale, there is virtually no limit to what the organisation can achieve in online marketing that changes every minute with proper coordination of Big data.

There are several other marketing trends that worth mentioning including social media messenger apps (lots can be achieved by sharing captivating message or video in messenger Apps that house over one billion users in the globe. Visual search is also a powerful marketing tools employed by marketers to market their products among others.

\section{CONCLUSION AND FUTURE RESEARCH}

In this study tries to offer some valuable insight into the relationship between E-Marketing Mix Element between Customer Relationship Management. Researcher discuss the major elements contributing to the success of e-marketing and proposed that any newly formed business or existing businesses should prudently study and examine the emarketing strategy and IMC before making investment in business activities. The 4 Ps marketing mix was created in the early days of the marketing concept when physical products, physical distribution and mass communication were dominant.

In today business environment created by the different and empowered capabilities of digital contexts, the marketing mix paradigm increasingly becomes object of criticism. When emarketing research and practice will arrive to a deeper comprehension and maturity in the digital environment, we 


\section{International Journal of Engineering Applied Sciences and Technology, 2020 \\ Vol. 5, Issue 6, ISSN No. 2455-2143, Pages 40-48 \\ Published Online October 2020 in IJEAST (http://www.ijeast.com)}

will probably see a new marketing mix paradigm which will definitely put to the traditional 4 Ps to rest and give light to a new widely accepted paradigm for marketing operations.

The framework of E-marketing mix has yet not to validated as a valid framework. Such framework should validate by the expert in thins form of knowledgeable E-marketing expert and successful E-business entrepreneurs. For future researcher, there is possibility for future researcher to investigate in deeper on whether marketing mix could affect customers loyalty, perception, experience and security in online purchase. Other than that, the researcher also can focus more on Customer Relationship Management in order to improve to improve product/service awareness.

\section{REFERENCE}

[1] bin Abdul Lasi, M., \& Man, T. C. (2020). The Impact of Marketing Mix Elements on Brand Loyalty towards Speech Therapy in Health Science Industry Malaysia. American Journal of Industrial and Business Management, $10, \quad 1575-1585$. https://doi.org/10.4236/ajibm.2020.109100.

[2] Azahari Jamaludin, et. al. "The Relationship between EMarketing Strategy and Competitive Advantage: A Conceptual Framework" International Journal of Managerial Studies and Research (IJMSR), vol 6, no. 12, 2018, pp.19-25.

[3] McCarthy, Jerome E. (1964). Basic Marketing. A Managerial Approach. Homewood, IL: Irwin

[4] Keelson, S.A>, "The Evolution of the Marketing Concepts: Theoretically Different Roads Leading to Practically the Same Destination!" in Global Conference on Business and Finance Proceedings, Volume 7, Number 1, 2012, ISSN 1941-9589

[5] Ahamed Kamarullkhsan Bin Ahamed Zaki and Masri Bin Abdul Lasi (2020); The Effect Of Service Quality On Customer Satisfaction Towards Loyalty And Happiness In Shared Service Company: A Study On Global Business Service Hub In Malaysia Int. J. of Adv. Res. 8 (Sep). 311320] (ISSN 2320-5407). www.journalijar.com

[6] Meng, S. K., \& Chatwin, C. (2012). Measuring EMarketing Mix Elements for Online Business. International Journal of E-Entrepreneurship and Innovation (IJEEI), 3(3), 13-26. doi:10.4018/jeei.2012070102

[7] Kotler, P., \& Armstrong, G. (2010).Principles of Marketing, Thirteenth Edition-Global Edition, Pearson Education, Inc., Upper Saddle River, NJ. 07458.

[8] Kalyanam, K., \& McIntyre, S. (2002). The E-Marketing Mix: A Contribution of the E-Tailing Wars, Department of Marketing, Leavey School of Business, Santa Clara University, Santa Clara, CA 95053

[9] Azahari, J., Raemah, A. H., \& Yasmin, Y. (Dec. 2013). Developing Malaysian Micro Entrepreneur Through EBusiness. MARA Innovation Journal, Vol. 2 Issue 02. ISSN: 2289-2818.

[10] Van Waterschoot, W., \& Van den Bulte, C. (1992). The 4P Classification of the Marketing Mix Revisited. Journal of Marketing, 56(4), 83-93.

[11] Noor Raihan Ab Hamid, \& Ali Khatibi (2006). How Effective are Firms' E-Marketing Tools? Procceding of the $5^{\text {th }}$ WSEAS International Conference on EACTIVITIES (pp.183-188). Venice Italy.

[12] Tangsupwattana, W. and Liu, X. (2018), "Effect of emotional experience on symbolic consumption in Generation Y consumers", Marketing Intelligence \& Planning, Vol. 36 No. 5, pp.

[13] Orasmäe, A. (2017). Integrated Marketing Communication. Dessertation submitted to Helsinki Metropolia University of Applied Sciences.

[14] Pawar, A. V. (2014). study of the effectiveness of online marketing on integrated marketing communication. Navi Mumbai: Dessertation submitted to D.Y. Patil University

[15] Helen, A. (2018, 06 27). the steps in developing an integrated marketing communication plan. Retrieved from Chron: https://smallbusiness.chron.com/steps-developingintegrated- marketing-communication-plan-56305.

[16] Caemmerer, B. (2009). The planning and implementation of integrated marketing communications. Journal of Marketing Intelligence \& Planning, 27(4), 526-529.

[17] Preeti, V. (2018). The effectiveness of e-marketing on integrated marketing communication

[18] Rahul, J. J. (2016). study of the effectiveness of online marketing on integrated marketing communication. Mumbai: dessertation submitted to university of Mumbai.

[19] Weinstein, L. (2008). Technology adoption and performance in the sales force. Proquest Dissertation and Thesis (online). Retrieved from Proquest: http://search.proquest.com/docview/304642054?accountid $=10612$

[20] Aron. O, \& Nima, H. (2015). Mastering the complementarity between marketing mix and customerfocused capabilities to enhance new product performance. Journal of Business \& Industrial Marketing. 30/1 (2015) 60-71. DOI 10.1108/JBIM-07- 2012-0124

[21] Nebojsa, S.D. \& Piyush, S. (2015). Impact of product differentiation, marketing investments and brand equity on pricing strategies: A brand level investigation. European Journal of Marketing. Vol. 49 No. 5/6, 2015. pp. 760-781. Retrieved from www.emeraldinsight.com/0309-0566.htm 
[22] John G. D. (2017). Price promotions: examining the buyer mix and subsequent changes in purchase loyalty. Journal of Consumer Marketing. 35/4 (2018) 366-376. DOI 10.1108/JCM-03-2017-2134

[23] Leandro, A.G., Juan, M.S., Jonny, M.R. (2018). Price and in-store promotions in an emerging market. Marketing Intelligence \& Planning. Vol. 36 No. 4, 2018. pp. 498511. DOI 10.1108/MIP-08-2017-0154

[24] Rialti, R., Zollo, L., Pellegrini, M. M., \& Ciappei, C. (2017). Exploring the antecedents of brand loyalty and electronic word of mouth in social-media-based brand communities: Do gender differences matter? Journal of Global Marketing, 30(3), 147-160.

[25] Kim, S. J., Wang, R. J.-H., Maslowska, E., \& Malthouse, E. C. (2016). "Understanding a fury in your words": The effects of posting and viewing electronic negative wordof-mouth on purchase behaviors. Computers in Human Behavior, 54, 511-521.

[26] Laura,G. , Maria, C.M. \& Angelo, D.G. (2015). Pre-event marketing and territorial governance: the case of Monza and Brianza province. Qualitative Market Research: An International Journal Vol. 19 No. 2, 2016. pp. 173-203. DOI 10.1108/QMR-02-2016-0009

[27] Abdelwahab. Aldukali. Ali. Alrawimi (2015), Influence of Online Security, Protection, Website Credibility and Previous after Sales Experience on The Intention to Purchase Online, European Journal of Business and Innovation Research, vol.3, no2, pp.1-10.

[28] Forbe. (2017, 02 03). video marketing the future of content marketing. Retrieved from Forbe:https://www.forbes.com/sites/forbesagencycouncil/ 2017/02/03/video-marketing-the- future-of-contentmarketing/\#7c48e1f36b53

[29] Demers. (2017, 12 28). 7 online marketing trend that will shape 2018. Retrieved from forbes: https://www.forbes.com/sites/jaysondemers/2017/12/28/7 -online-marketing-trends- that-will-dominate2018/\#31a0293b2c19

[30] Nidhi, D. (2018). 11 digital marketing trends you can no longer ingnore in 2018. Retrieved from Single grain: https://www.singlegrain.com/digital-marketing/11-digitalmarketing-trends- you-can-no-longer-ignore-in-2018/

[31] Brian, M. (2018, 06 30). online marketing. Retrieved from Grin: https://www.grin.co/blog/online- marketingtrends

[32] Strauss, J., \& Raymong, F. (1999). principle of online marketing . New Jersey: Prentice Hall. 